\title{
DESIGNING A SYSTEM DYNAMICS MODEL OF SHADOW WAGE FORMATION IN UKRAINE
}

\author{
๑2020 NOVIK A. YU.
}

UDC 331.5

JEL: J31; J33; J46; K42; 017

\section{Novik A. Yu. Designing a System Dynamics Model of Shadow Wage Formation in Ukraine}

The formation of the shadow wage in Ukraine is a major problem and a threat to economic growth. According to different valuation methods, the shadow economy in Ukraine ranges from $35 \%$ to $54 \%$ of GDP, and the shadow wage is estimated at $18 \%$ of GDP. The general scheme for tax evasion by businesses is to informally pay cash to workers in "envelopes", which results in a large amount of cash in the economy and, as a consequence, further opportunities for tax evasion. Despite the urgency of the current issue for Ukraine and a large number of works by Ukrainian and foreign scientists dedicated to finding positive and negative features of the existence of shadow wages, there is still a lack of research that determines the formation of shadow wages through the use of economic and mathematical tools. Based on that, a model of shadow wage formation using the system dynamics method was constructed, which takes into account such factors as the amount of cash in the economy and the size of the minimum wage. Based on the modeling results it was found that raising the minimum wage would reduce the share of the shadow component in GDP. Taking that into consideration, conclusions were drawn regarding the first objectives of government policy, which should aim at creating opportunities for economic growth and reducing the amount of cash in the economy in order to lower the size of the shadow sector in Ukrainian economy as a whole.

Keywords: shadow wage, system dynamics, imitation modeling, shadow economy drivers, shadow flows, feedback loops.

DOI: $h$ ttps://doi.org/10.32983/2222-4459-2020-1-122-128

Fig.: 4. Tabl.: 3. Bibl.: 11.

Novik Alina Yu. - Assistant, Department of Finance, National University of "Kyiv-Mohyla Academy" (2 H. Skovorody Str., Kyiv, 04655, Ukraine)

E-mail:novikaj@ukma.edu.ua

ORCID: https://orcid.org/0000-0001-7139-2214

Researcher ID: https://publons.com/researcher/3355714/alina-novik/

УДК 331.5

JEL: J31; J33; J46; K42; 017

Новік А. Ю. Побудова моделі системної динаміки формування тіньової зарплати в Україні

Формування тіньової заробітної плати в Україні $\epsilon$ великою проблемою та загрозою для економічного зростання. Відповідно до різних методів оцінки, тіньова економіка в Україні коливається від $35 \%$ до 54\% ВВП, а тіньова заробітна плата оцінюється у 18\% від вВП. Загальна схема ухилення від сплати податків підприємствами полягає в неофіційних виплатах готівкових коштів для працівників у "конвертах», що спричиняє велику кількість готівки в економіці та, як наслідок, надає ще більше можливостей для подальшого ухилення від сплати податків. Незвањаючи на актуальність поточного питання для України та велику кількість праць вітчизняних і зарубіжних учених, присвячених пошуку позитивних і негативних рис існування тіньової заробітної плати, все ще бракує досліджень, які визначають формування тіньової заробітної плати шляхом використання економіко-математичного інструментарію. Враховуючи це, побудовано модель формування тіньових заробітних плат за допомогою методу системної динаміки, що полягає у врахуванні таких факторів, як кількість готівкових коштів в економіці та розмір мінімальної заробітної плати. На основі побудованої моделі наведено результати, виходячи з яких встановлено, що підвищення рівня мінімальної заробітної плати приведе до зменшення частки тіньової складової у ВВП. Базуючись на отриманих результатах, сформовано висновки щодо першочергових завдань урядової політики, яка має бути спрямована на створення можливостей для економічного зростання та на зменшення суми готівкових коштів в економіці з метою зменшення обсягу тіньового сектора загалом.

Ключові слова: тіньова заробітна плата, системна динаміка, імітаційне моделювання, фактори формування тіньової економіки, тіньові потоки, петлі зворотного зв'язку.

Рис.: 4. Табл.: 3. Бібл.: 11

Новік Аліна Юріївна - асистент, кафедра фінансів, Національний університет "Києво-Могилянська академія" (вул. Г. Сковороди, 2, Київ, 04655, Україна)

E-mail:novikaj@ukma.edu.ua

ORCID: https://orcid.org/0000-0001-7139-2214

Researcher ID: https://publons.com/researcher/3355714/alina-novik/

УДК 331.5

JEL: J31; J33; J46; K42; 017

Новик А. Ю. Построение модели системной динамики формирования теневой зарплаты в Украине

Формирование теневой заработной платы в Украине является большой проблемой и угрозой для экономического роста. Согласно различным исследованиям и методам оценки, теневая экономика в Украине колеблется от 35\% до 54\% ВВП, а теневая заработная плата оценивается в $18 \%$ от ВВП. Общая схема уклонения от уплаты налогов предприятиями заключается в неофициальных выплатах наличных средств для работников в "конвертах», что вызывает большое количество наличных денег в экономике, и, как следствие, предоставляет еще больше возможностей для дальнейшего уклонения от уплаты налогов. Несмотря на актуальность текущего вопроса для Украины и большое количество работ отечественных и зарубежных ученых, посвященных поиску положительных и отрицательных черт существования теневой заработной платы, все еще не хватает исследований, определяющих формирование теневой заработной платы путем использования экономико-математического инструментария. Учитывая это, построена модель формирования теневых заработных плат при помощи метода системной динамики, которая учитывает такие факторы, как количество наличных средств в экономике и размер минимальной заработной платы. При помощи построения модели представлены результаты, на основании которых установлено, что повышение уровня минимальной заработной платы приведет к уменьшению доли теневой составляющей в ВВП. Базируясь на полученных результатах, ссормированы выводы относительно неотложных задач правительственной политики, которая должна быть направлена на создание возможностей для экономического роста и уменьшение суммы наличных средств в экономике с целью уменьшения объема теневого сектора в целом. 
Ключевые слова: теневая заработная плата, системная динамика, имитационное моделирование, факторы формирования теневой экономики, теневые потоки, петли обратной связи.

Рис.: 4. Табл.: 3. Библ.: 11.

Новик Алина Юрьевна - ассистент, кафедра финансов, Национальный университет "Киево-Могилянская академия" (ул. Г. Сковороды, 2, Киев, 04655, украина)

E-mail: novikaj@ukma.edu.ua

ORCID: https://orcid.org/0000-0001-7139-2214

Researcher ID: https://publons.com/researcher/3355714/alina-novik/

A $t$ the present stage of economic development, Ukraine is characterized by a high level of the shadow economy, which influences effectiveness of all socio-economic spheres and slows down economic growth. Moreover, it plays a special role in the functioning and regulation of the labor market through a high share of disguised remuneration schemes. The prerequisites for the emergence and functioning of the shadow component are a low level of economic development of Ukraine, the lack of confidence in public institutions, which is caused by the lack of social guarantees, and inefficient legislation on the regulation of monetary transactions. In this regard, the Pension Fund receives a smaller share of taxes, which causes a low level of retirement benefits, as well as abolishes social guarantees for employees who receive envelope wages.

A high level of the shadow economy in Ukraine has several advantages and disadvantages. Due to low economic growth and inefficient allocation of public funds, public confidence in the state is low and leads to the tendency of avoiding taxes. There are two main ways of tax avoidance by employers: payment of envelope wages in part or in full, which allows the employer to reduce tax burden by not reflecting in the enterprise's financial reporting the actual number of employees and reducing the declared wages. The negative feature of this scheme is the deprivation of a social security of an employee due to a low share of taxes paid to the budget. Another way used to avoid taxes is to register as individual entrepreneurs, who are subject to a simplified tax system to support small and medium-sized businesses. The existence of such schemes contributes to a decrease in the internal pressure on the labor market in the short term but poses certain threat to the national economic security, which is in the state's not receiving potential tax revenues. This will lead to higher tax rates in the long run, cause even greater distrust of government institutions and thus intensify the desire for tax avoidance. Moreover, such schemes result in distorting statistical information of the number of employed persons and the proportion of the economically active population as well as emerging hidden employment due to the lack of the need to be registered with the public employment service.

Problems of development, regulation, reformation of the labor market, formation of wages were studied by a number of scientists including: V. Blyzniuk, V. Petiukha, I. Bondar, E. Libanova, A. Kolota, O. Kupets, I. Lukianen- ko, D. Bohynia, M. Vedernikova, V. Danylyshyn, O. Stefankiv, and others. In recent decades, particular attention has been paid to the high level of the economy shadow and the intensification of migration processes. The main findings of these studies are that despite the primary benefit to the employee and employer in the form of easing the pressure of taxation, the state deprives workers who receive envelope wages of such social guarantees as pensions, sick pays, and unemployment compensation [1]. It has also been previously determined that tax avoidance is highly likely to be caused by an imperfect tax system, which poses a greater tax burden on the lower-income population, as well as a high level of corruption, which leads to inefficient distribution of funds and dissatisfaction of the population with the quality of public goods received [2]. Due to the fact that according to different estimates the shadow economy in Ukraine is between 35 and $54 \%$ of the GDP, standard ways of solving economic problems in the country not effective [3]. Despite the inadequate tax scheme and the government's repeated emphasis on the need to combat schemes related to individual entrepreneurship, this type of tax avoidance is not illegal and is not associated with the shadow economy, as employees are officially employed and receive all social guarantees from the state while paying less. According to estimates of the State Statistics Committee of Ukraine, in different years, the economy of the country lost from 14 to $20 \%$ of the GDP due to the shadow sector, but this estimate is not accurate [4]. Given the above information, to effectively regulate the labor market and remove the shadows from the economy, it is, first of all, necessary that the government create an effective apparatus for combating tax avoidance at enterprises. Developing an effective cash flow regulation is an important step in reducing the share of undeclared payments, however, a too sharp decrease can have negative consequences for the economy, in particular, a decline in business activities and increase in emigration from Ukraine.

$\mathrm{D}$ espite a large amount of studies considering disguised remuneration schemes, the issue of formation of illicit financial flows is still unexplored, and there is a lack of research using adequate economic and mathematical tools. In this regard, the main aim of the article is to model, with the help of the system dynamics method, a cumulative share of undeclared wages due to the formation of input and output illicit financial 
flows in the economy of Ukraine and, based on the results, to conduct the scenario analysis of its behavior.

Under the current conditions, the high level of shadow economy is a particular threat to national security. Studies have shown that the level of undeclared wages amounts to $18 \%$ of the total value of underground activity and $45 \%$ of the declared wages for all workers in Ukraine. Such a high level of shadow economy causes many problems for the country and deprives social security guarantees, which can lead to the loss of productive working age population. On the other hand, envelope wages help keep people from moving abroad, which can be a good effect in the short term, but will lead to distrust of government agencies in the long run. Before pursuing a pay rise policy, it is important to understand how this system works.

$\mathrm{T}$ o avoid taxes, enterprises officially pay the minimum wage to their employees. As a result, both enterprises and employees pay a less amount of taxes. At the same time, employees get envelope wages which are not reflected it in enterprises' financial statement. According to the legislation of Ukraine, banks have the right to conduct monitoring of individual accounts to prevent money laundering. Transactions between accounts can be traced, therefore, in order to avoid revealing transfers of shadow funds, enterprises pay part of their wages to employees in cash. The estimation of cash in monetary aggregates by the National Bank of Ukraine shows that in 2019 the M0 (cash) share in M3 is lower than in 2000 [5; 4], but is still estimated to be approximately $27 \%$ in the money supply and approximately $52 \%$ in the monetary aggregate M1, which is presented in Fig. 1. Such a large amount of cash in the economy stimulates underground activity, and it is clear that this activity enhances the use of cash.

Multiple researches show that the amount of cash in the economy stimulates intensification of illicit financial flows, and, according to different methods, the amount of cash in M3 or alternatively in M1 are the main indicators which are used for measuring the level of shadow economy in different countries [6]. Based on

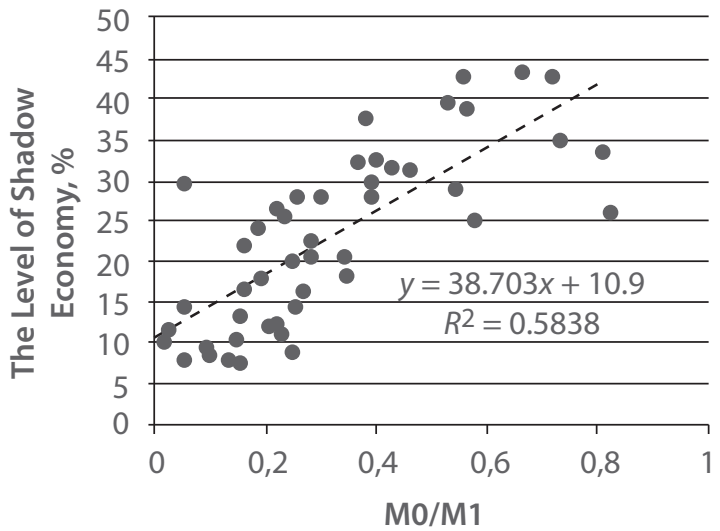

this information, it was decided to measure the impact of both ratios on the level of shadow economies in different countries. Since the ultimate goal of modeling is to build a simulation model, it is reasonable to choose one of the methods by comparing the effects of the two above ones with the help of a simple regression analysis, which is represented in Fig. 1.

A ccording to the results obtained, the effect of the amount of cash in M3 monetary aggregate is insignificant since the coefficient of determination is 0.08 , in contrast to the influence of the amount of cash in M1 monetary aggregate, for which the coefficient of determination is 0.58 . This indicates that there is a relationship between the shadow economy and the share of cash in M1 monetary aggregate. Thus, it is this measure that will be used for further simulation. In Ukraine, the share of M0 in M1 monetary aggregate equals to $55 \%$, while in countries with lower level of shadow economy, this amount varies between $10-30 \%$ [6; 7].

The main hypotheses that were formulated to build a simulation model of the emergence and transformation of financial flows associated with shadow wages in Ukraine are shown in $T b l .1$.

Based on the formulated hypotheses, a simulation model was constructed using the system dynamics method, which shows the mechanism of formation and transformation of financial flows associated with envelope wages. The main element in the model is the accumulated value of shadow wages in Ukraine, which is increased by paying envelope wages and decreased by reporting transactions carried out. The logic behind the combination of hypotheses is shown schematically in the diagram of cause and effect relationships (Fig. 2).

When building system dynamics models and interpreting them, the basic requirements are to determine the types of relations (accumulative and instantaneous) and the types of feedback loops (balancing and reinforcing) [11]. The main requirement for the model to return to equilibrium is the presence of balancing feedback loops with delays (stocks). The main stock in the model

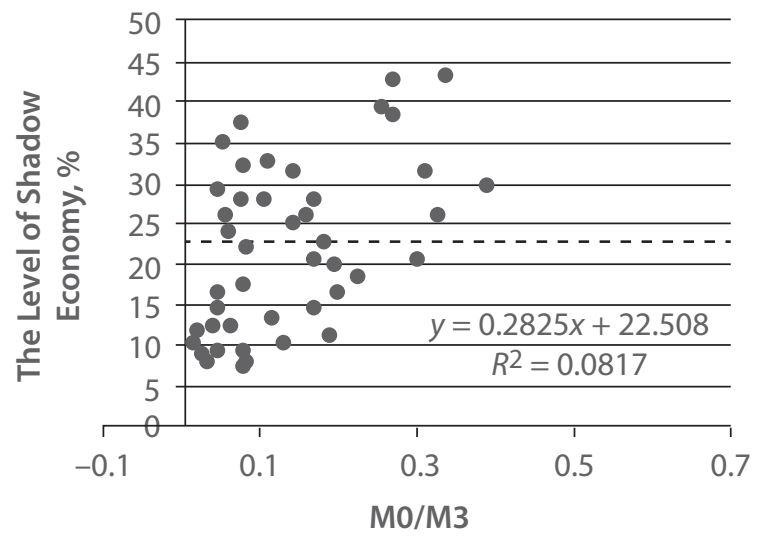

Fig. 1. Dependency of shadow economy based on M0/M1 and M0/M3 ratios

Source: developed by the author based on [6-8]. 
The main hypotheses of the formation of financial flows associated with shadow wages

\begin{tabular}{|l|l|}
\hline \multicolumn{1}{|c|}{ Hypothesis } & \multicolumn{1}{c|}{ Explanation } \\
\hline $\begin{array}{l}\text { 1. The weight of the monetary aggregate M0 in the money } \\
\text { supply has a positive effect on financial flows associated with } \\
\text { shadow wages }\end{array}$ & $\begin{array}{l}\text { A high share of cash in the money supply contributes to the } \\
\text { possibility of carrying out informal transactions in the form of } \\
\text { envelope wages }\end{array}$ \\
\hline $\begin{array}{l}\text { 2. Increasing the accumulated value of the shadow wages } \\
\text { positively contributes to the increase in the share of the mo- } \\
\text { netary aggregate M0 in the monetary aggregate M1 }\end{array}$ & $\begin{array}{l}\text { A higher amount of shadow salary will increase the share of } \\
\text { cash in the money supply, which will increase shadow wages } \\
\text { in the future }\end{array}$ \\
\hline $\begin{array}{l}\text { 3. The total amount of wages is calculated as the average on } \\
\text { the job market for such vacancies, thus shadow wages are } \\
\text { determined as the difference between the total amount of } \\
\text { wages and that of officially declared wages }\end{array}$ & $\begin{array}{l}\text { Employers can avoid payroll taxes by reducing the proportion } \\
\text { of the declared wages. The scheme of paying wages in the } \\
\text { amount of the minimum wage with the rest of the money be- } \\
\text { ing handed out in the form of envelope wages is common }\end{array}$ \\
\hline $\begin{array}{l}\text { 4. Reducing the share of shadow money received in the form } \\
\text { of envelope wages occurs through the implementation of } \\
\text { declared transactions in cash }\end{array}$ & $\begin{array}{l}\text { These transactions are cash payments for any transaction re- } \\
\text { corded by fiscal registrars }\end{array}$ \\
\hline $\begin{array}{l}\text { 5. The shadow supplement to declared wages will decrease } \\
\text { with an increase in the minimum wage }\end{array}$ & $\begin{array}{l}\text { If the minimum wage increases, the share of the shadow } \\
\text { wages supplement will decrease, which will help reduce the } \\
\text { amount of the shadow wage supply in the economy }\end{array}$ \\
\hline
\end{tabular}

Source: developed by the author based on $[3 ; 5 ; 6]$.

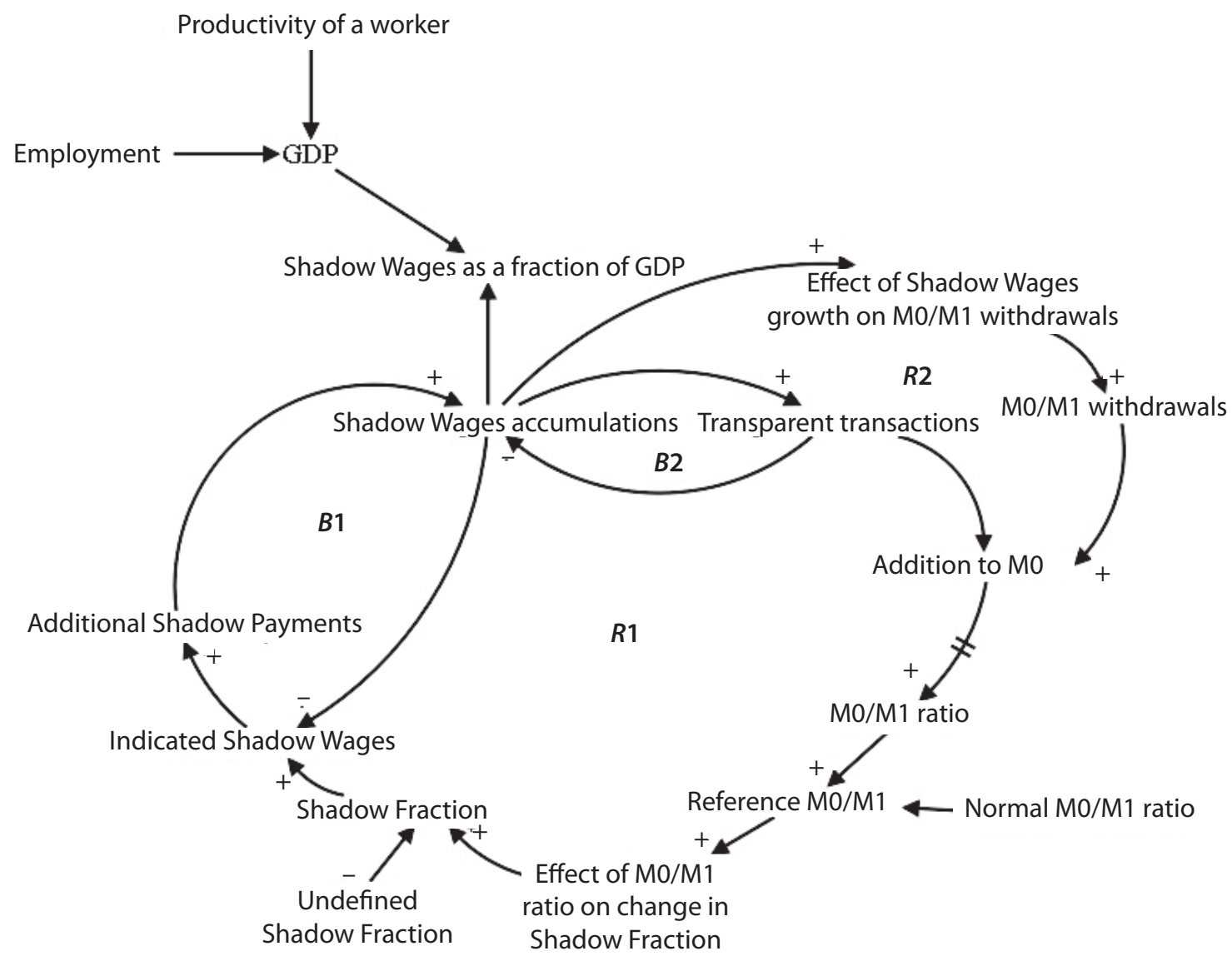

Fig. 2. Causal loop diagram of shadow wage formation

Source: developed by the author based on $[5 ; 6 ; 10]$ in Stella Architect software.

is the variable of shadow wage accumulations. Based on the analysis of the constructed cause and effect diagram shown in Fig. 1, four feedback loops were identified: two balancing and two reinforcing ones. A detailed analysis of the loops is presented in Tbl. 2.
Based on the CLD, the stock and flow diagram was built and simulated. Taking into consideration that the main element of the model, the cumulative shadow wages, is a stock, its equation is: 
The main feedback loops in the model

\begin{tabular}{|c|l|l|}
\hline Loop & \multicolumn{1}{|c|}{ Type } & \multicolumn{1}{c|}{ Explanation } \\
\hline B1 & Balancing & $\begin{array}{l}\text { If the current cumulative level of shadow wages is equal to the new one, which is formed based on } \\
\text { the hypotheses as to an increase of the share of the monetary aggregate M0 in the money supply, } \\
\text { the accumulated wage will be constant. Provided there is a positive (negative) gap between the } \\
\text { current level of accumulative shadow wages and a certain level of new shadow wages, the ac- } \\
\text { cumulated wages will increase (decrease) up to the time when the gap between them disappears } \\
\text { and the system comes to equilibrium }\end{array}$ \\
\hline B2 & Balancing & $\begin{array}{l}\text { A higher amount of illegal payments due to shadow wages contributes to a higher number of } \\
\text { declared transactions, which, as a consequence, helps to reduce the amount of illegal payments in } \\
\text { the economy }\end{array}$ \\
\hline R1 & Reinforcing & $\begin{array}{l}\text { Declared transactions are carried out by withdrawing cash from the shadows and using them for } \\
\text { calculations recorded by fiscal registrars. The calculation of cash in circulation is used to determine } \\
\text { its share in the money supply, and, as a consequence, positive or negative effect of change in this } \\
\text { value on the new calculated level of shadow wages. Thus, increasing cash in circulation without } \\
\text { stimulating the transition to non-cash payments will contribute to a larger share of shadow wages } \\
\text { in the total amount of wages }\end{array}$ \\
\hline R2 & Reinforcing & $\begin{array}{l}\text { The value of the accumulated shadow wages has a positive effect on the cash share in M1 mon- } \\
\text { etary aggregate. The greater the amount of envelope wages is, the less the share of cash compared } \\
\text { to non-cash payments is }\end{array}$ \\
\hline
\end{tabular}

Source: developed by the author based on $[6 ; 10]$.

$$
S h W_{t}=\int_{0}^{t}\left(\begin{array}{l}
\text { shadow } \mathrm{sec} \text { tor raise }- \\
\text { transparent transactions }
\end{array}\right) d t+S h W_{0},
$$

where $S h W_{t}$ - is a stock of accumulated shadow wages in the current period of time;

shadow sector raise - is the inflow to shadow wage stock;

transparent transactions - is the outflow from the shadow wage stock;

$S h W_{0}$ - is the initial amount of shadow wages in the economy.

The variable shadow sector raise is calculated as a sum of indicated shadow wages, which is formed based on the M0/M1 ratio effect on the shadow wage formation and the total wages, which is the sum of the declared and shadow parts. The formation of the total wages is calculated as showed in Fig. 3.

1 he main idea behind the total minimum wage calculation is that it equals the product of the data on the minimum wage, based on the data on its real values, and the multiplier of the declared wages. This calculation allows to demonstrate the potential for its increase. This multiplier influences the fraction of envelope wages, which means that the higher the minimum wage is, the less the opportunity for the enterprise to pay additional money to the declared amount will be. Taking into consideration that there is no data available, this is just a simulation based on the idea of minimizing the shadow payments by increasing the minimum wage. As a result, the weight of

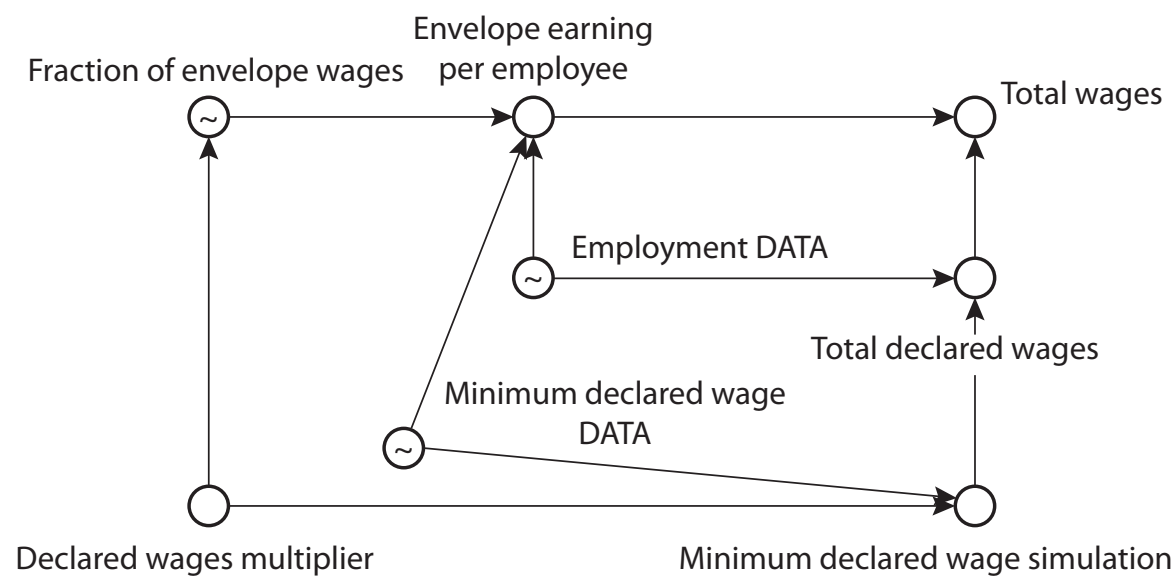

Fig. 3. The formation of the total wages

Source: created by the author in Stella Architect Software based on [3]. 
declared wages in the total wages will increase. The results of the simulation are represented in Fig. 4.

The blue line on a graph represents the base line when multiplier equals to 1 . In this case, the ratio of shadow wage to GDP is approximately $18.4 \%$, which was mentioned in previous research. Based on the retrospective scenarios, an increase in the minimum wage multiplier will lead to a decrease in shadow wages, thus, if the minimum wage would be 4 times higher than its original level, the shadow wage to GDP ratio would be $7 \%$, which is more than 2 times lower than the current level. The simulation results are presented in Tbl. 3 .

\section{CONCLUSIONS}

Based on the results of the model presented in this article, the main conclusions are that the primary tasks of the government are to increase the minimum wage in order to reduce the amount of shadow wages in the economy. To achieve the goal, the government should conduct a policy to enhance economic growth by attracting specialists into upcoming sectors with high officially declared payments, which will ensure social guarantees for employees. Also, it is worth redistributing government expenditures, allocating more funds to finance research and development projects, and pursuing a policy to attract capital investment. Such measures will contribute to the development of human capital and, accordingly, increase labor productivity in Ukraine, which will positively affect production volumes, and as a result will lead to an increase in income and wages. Moreover, the amount of cash in M1 aggregate in the economy should be reduced to close the opportunities for shadow growth, which will lead to ensuring higher standards of living of population.

\section{LITERATURE}

1. Приступа Т. В., Чайковська М. А. Тіньова економіка та їі вплив на соціально-економічний розвиток України. Приазовський економічний вісник. 2019. Вип. 1. С. 56-61. URL: http://pev.kpu.zp.ua/ journals/2019/1_12_uk/11.pdf

2. Носова Є. А. Тіньова заробітна плата в Україні: причини існування та шляхи подолання. Сочіально-

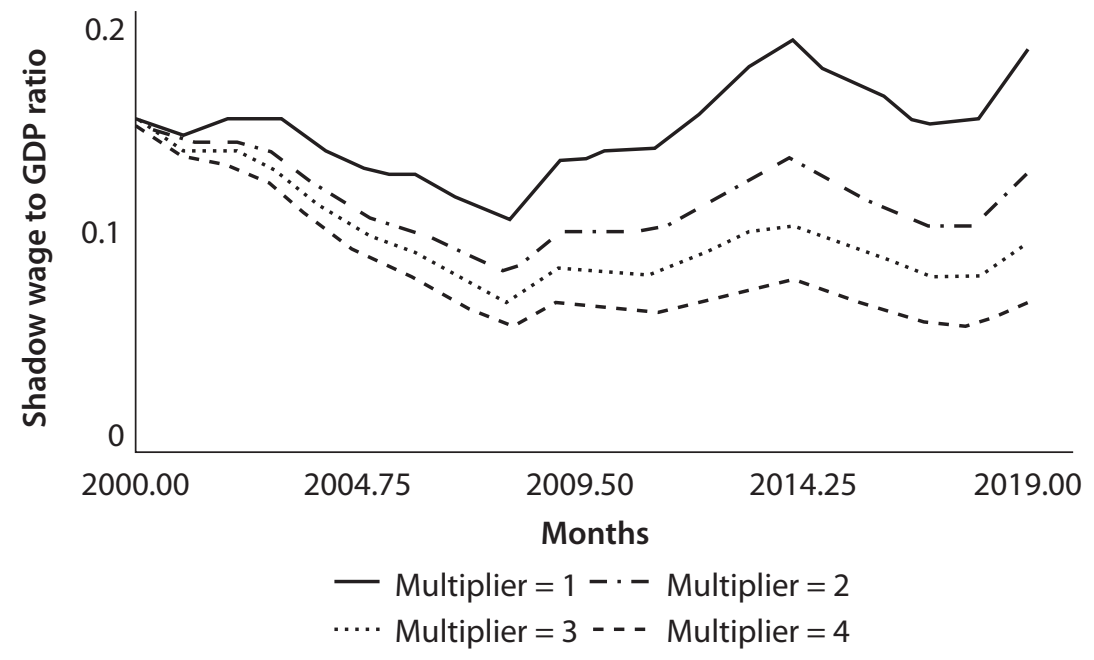

Fig. 4. Retrospective of the shadow wage formation based on different values of the multiplier parameter Source: created by the author in Stella Architect software based on [6].

Table 3

The share of shadow wage in GDP

\begin{tabular}{|c|c|c|c|c|}
\hline Year & Multiplier = 1 & Multiplier = 2 & Multiplier = 3 & Multiplier=4 \\
\hline 2010 & 0.136494288 & 0.102169869 & 0.084161277 & 0.067549727 \\
\hline 2011 & 0.138414074 & 0.101878721 & 0.082710143 & 0.065028596 \\
\hline 2012 & 0.15391699 & 0.111809793 & 0.089717901 & 0.069339819 \\
\hline 2013 & 0.174331049 & 0.12534801 & 0.09964865 & 0.075942955 \\
\hline 2014 & 0.187089372 & 0.133448695 & 0.105305666 & 0.079345873 \\
\hline 2015 & 0.170286193 & 0.120729156 & 0.094728643 & 0.070745157 \\
\hline 2016 & 0.160133775 & 0.11297319 & 0.088229996 & 0.065406291 \\
\hline 2017 & 0.149295387 & 0.104672912 & 0.081261359 & 0.05966599 \\
\hline 2018 & 0.152289831 & 0.105985148 & 0.081691009 & 0.059281523 \\
\hline 2019 & 0.183876916 & 0.127193807 & 0.09745454 & 0.070022341 \\
\hline
\end{tabular}


трудові відносини: теорія та практика. 2013. № 2. C. $110-115$.

3. Рева А. Тіньова економіка та зарплати в конвертах породжують бідність і позбавляють українців права на соціальний захист // Урядовий портал. 18.04.2018. URL: https://www.kmu.gov. ua/news/andrij-reva-tinova-ekonomika-ta-zarplativ-konvertah-porodzhuyut-bidnist-i-pozbavlyayutukrayinciv-prava-na-socialnij-zahist

4. Харазішвілі Ю. М. Світло і тінь економіки України: резерви зростання та модернізації. Економіка України. 2017. № 4. C. 22-45.

5. Monetary and Financial Statistics. National Bank of Ukraine. 2019. Feb. 14 p. URL: https://old.bank.gov.ua/ doccatalog/document?id=94653097

6. Medina L., Schneider F. Shadow Economies Around the World: What Did We Learn Over the Last 20 Years? IMF Working Paper. 2018. No. 18/17. 76 p. DOI: $10.5089 / 9781484338636.001$.

7. Money Supply MO. Trading Economics. URL: https:// tradingeconomics.com/country-list/money-supply-m0

8. Money Supply M1. Trading Economics. URL: https:// tradingeconomics.com/country-list/money-supply-m1

9. Money Supply M3. Trading Economics. URL: https:// tradingeconomics.com/country-list/money-supply-m3

10. Новік А. Ю. Моделювання процесів внутрішньої міграції за допомогою методу системної динаміки. Наукові записки НаУКМА. Серія «Економічні науки». 2017. Т. 2. Вип. 1. С. 103-109.

DOl: https://doi.org/10.18523/2519-4739212017119815

11. Lukianenko I., Novik A. The Ukrainian Labor Market Investigation with the Use of System Dynamics Methods. Наукові записки НаУКМА. Серія «Економічні науки». 2016. Vol 1. Вип. 1. Р. 106-117.

DOI: https://doi.org/10.18523/2519-4739112016124804

Scientific adviser - Lukianenko I. G., Doctor of Economics, Professor, Head of the Department of Finance, National University "Kyiv-Mohyla Academy"

\section{REFERENCES}

Kharazishvili, Yu. M. "Svitlo i tin ekonomiky Ukrainy: rezervy zrostannia ta modernizatsii" [Light and Shadow of the Economy of Ukraine: Reserves for Growth and Modernization]. Ekonomika Ukrainy, no. 4 (2017): 22-45.
Lukianenko, I., and Novik, A. "The Ukrainian Labor Market Investigation with the Use of System Dynamics Methods". Naukovi zapysky NaUKMA. Seriia "Ekonomichni nauky», vol. 1, no. 1 (2016): 106-117. DOl: https://doi.org/10.18523/2519-4739112016124804.

"Monetary and Financial Statistics". National Bank of Ukraine. 2019. https://old.bank.gov.ua/doccatalog/ document?id=94653097

"Money Supply M0. Trading Economics". https://tradingeconomics.com/country-list/money-supply-m0

"Money Supply M1. Trading Economics". https://tradingeconomics.com/country-list/money-supply-m1

"Money Supply M3. Trading Economics". https://tradingeconomics.com/country-list/money-supply-m3

Medina, L., and Schneider, F. "Shadow Economies Around the World: What Did We Learn Over the Last 20 Years?" IMF Working Paper, no. 18/17 (2018). DOI: $10.5089 / 9781484338636.001$.

Nosova, Ye. A. “Tinyova zarobitna plata v Ukraini: prychyny isnuvannia ta shliakhy podolannia" [Shadow wages in Ukraine: Reasons for Existence and Ways to Overcome It]. Sotsialno-trudovi vidnosyny: teoriia ta praktyka, no. 2 (2013): 110-115.

Novik, A. Yu. "Modeliuvannia protsesiv vnutrishnyoi mihratsii za dopomohoiu metodu systemnoi dynamiky" [Modeling of Internal Migration Processes Using the System Dynamics Method]. Naukovi zapysky NaUKMA. Seriia «Ekonomichni nauky», vol. 2, no. 1 (2017): 103-109. DOl: https://doi.org/10.18523/25194739212017119815.

Prystupa, T. V., and Chaikovska, M. A. "Tinyova ekonomika ta yii vplyv na sotsialno-ekonomichnyi rozvytok Ukrainy" [The Shadow Economy and her Influence on the Social and Economic Development of Ukraine]. Pryazovskyi ekonomichnyi visnyk. 2019. http://pev. kpu.zp.ua/journals/2019/1_12_uk/11.pdf

Reva, A. "Tinyova ekonomika ta zarplaty v konvertakh porodzhuiut bidnist i pozbavliaiut ukraintsiv prava na sotsialnyi zakhyst" [The Shadow Economy and Envelope Wages Create Poverty and Deprive Ukrainians of the Right to Social Protection]. Uriadovyi portal. 18.04.2018. https://www.kmu.gov.ua/news/andrijreva-tinova-ekonomika-ta-zarplati-v-konvertah-porodzhuyut-bidnist-i-pozbavlyayut-ukrayinciv-prava-nasocialnij-zahist 